\title{
Management and outcome of multifetal gestation in a 35-year- old woman with childhood-onset membranoproliferative glomerulonephritis type I
}

\author{
Osamu Motoyama ${ }^{1}\left[\right.$ Ken Sakai ${ }^{2} \cdot$ Kikuo litaka $^{3}$
}

Received: 11 June 2018 / Accepted: 5 August 2018 / Published online: 12 August 2018

(c) The Author(s) 2018

\begin{abstract}
A 35-year-old woman with membranoproliferative glomerulonephritis type I had quintuplet gestation after induced ovulation. Her serum creatinine level and estimated glomerular filtration rate were $0.86 \mathrm{mg} / \mathrm{dL}$ and $61.5 \mathrm{~mL} / \mathrm{min} / 1.73 \mathrm{~m}^{2}$ before pregnancy. Blood pressure was normal and urinary protein to creatinine ratio was $0.2 \mathrm{~g} / \mathrm{gCr}$. Prednisolone $10 \mathrm{mg}$ on alternateday administration was continued during pregnancy. At 10 weeks of gestation transvaginal selective embryo reduction was performed and five embryos were reduced to twins. Hypertension occurred at 20 weeks of gestation. She developed nephrotic syndrome and serum creatinine level increased to $1.29 \mathrm{mg} / \mathrm{dL}$. Elective cesarean section was performed at 28 weeks of gestation and dichorionic diamniotic twins were born. After delivery blood pressure, serum creatinine level, estimated glomerular filtration rate and serum albumin level in their mother returned to baseline. Her twin infants were well at discharge from neonatal-intensive-care-unit. Incidence of multifetal pregnancies due to the improvement of assisted reproduction technologies and ovulation-inducing hormones has been increasing. Management for multifetal pregnancy in women with chronic kidney disease will be needed further.
\end{abstract}

Keywords Assisted reproduction technology $\cdot$ Chronic kidney disease $\cdot$ Membranoproliferative glomerulonephritis type I Multifetal pregnancy

\section{Introduction}

Membranoproliferative glomerulonephritis (MPGN) type I is a chronic glomerulonephritis characterized by hypocomplementemia, mesangial proliferation and double contours glomerular capillaries on light microscopy, deposits of $\mathrm{C} 3$ along the capillary walls on immunofluorescent microscopy, and mesangial interposition and subendothelial electron dense deposits on electron microscopy. According to the earlier reports during 1980, poor outcome of pregnancy in women with MPGN type I was suggested [1,2]. In

Osamu Motoyama

024156mo@med.toho-u.ac.jp

1 Department of Pediatrics, Toho University Medical Center, Sakura Hospital, 564-1 Shimoshizu, Sakura-shi, Chiba 285-8741, Japan

2 Department of Nephrology, Toho University Medical Center, Omori Hospital, Tokyo, Japan

3 Hakuraku Renal Clinic, Kanagawa, Japan these reports the effects of hypertension, renal dysfunction or heavy proteinuria during pregnancy was not discussed. MPGN associated with hepatitis $\mathrm{C}$ virus infection was not excluded from idiopathic MPGN until 1993 [3]. Progress of obstetrical management and perinatal care improved prognosis of preterm and low birth weight infant $[4,5]$, even in women with chronic kidney disease (CKD) [6]. In recent years successful pregnancy in women with MPGN type I has been reported $[3,7,8]$. Incidence of multifetal pregnancies due to the improvement of assisted reproduction technologies and ovulation-inducing hormones has been increasing [9]. Multifetal pregnancies in women with CKD may increase. Clinical course of multifetal pregnancy in a woman with childhood-onset MPGN type I has not been reported to our knowledge. 


\section{Case report}

Microscopic hematuria and proteinuria were detected by school urinary screening when she was 10 years old. Edema and hypertension were not noted. Hypocomplementemia was detected and the serum levels of complement hemolytic activity (CH50), $\mathrm{C} 3$ and $\mathrm{C} 4$ were $24 \mathrm{U} / \mathrm{mL}$ (normal range $28-48 \mathrm{U} / \mathrm{mL}$ ), $21 \mathrm{mg} / \mathrm{dL}$ (normal range $64-166 \mathrm{mg} /$ $\mathrm{dL}$ ) and $19 \mathrm{mg} / \mathrm{dL}$ (normal range $15-38 \mathrm{mg} / \mathrm{dL}$ ), respectively. Microscopic hematuria, proteinuria and hypocomplementemia continued and she developed nephrotic syndrome (serum albumin level $2.5 \mathrm{~g} / \mathrm{dL}$ and urinary protein excretion $3.4 \mathrm{~g} /$ day) with normal blood pressure and renal function. The first renal biopsy was performed at 11 years of age and 30 glomeruli were obtained. Increase of mesangial cells and matrix with a lobular pattern of glomeruli and thick glomerular capillary walls with double contours were observed on light microscopic examination (Fig. 1). Subendothelial and mesangial deposits were observed on masson trichrome stain. There was no tubulointerstitial change. Lumpy $\mathrm{C} 3$ deposits along glomerular capillaries were demonstrated by immune-enzyme method (PAP method). There was weak staining of $\operatorname{IgA}, \operatorname{IgG}$ and $\operatorname{IgM}$ along glomerular capillaries. Glomeruli were not included in the specimen for electron microscopic studies. There were no clinical signs or symptoms of systemic lupus erythematosus, thrombotic microangiopathy and malignancies. AntiDNA antibody, hepatitis B virus antigen, hepatitis C virus antibody and cryoglobulins were negative. MPGN type I was diagnosed. Prednisolone (PSL) was started with $60 \mathrm{mg}$ ( $2 \mathrm{mg} / \mathrm{kg} /$ day) for 4 weeks and gradually reduced to $15 \mathrm{mg}$ on alternate days over 1 year period. Urinary protein excretion decreased to $2+$ by dipstick and hypoalbuminemia and

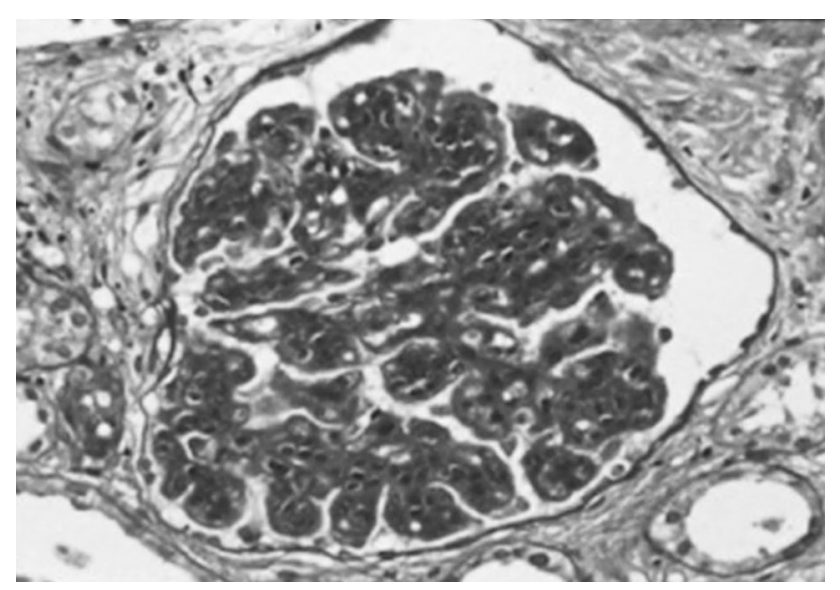

Fig. 1 Light micrograph of first renal biopsy performed at the age of 11 years old showing increase of mesangial cells and matrix with a lobular pattern of glomeruli and thick glomerular capillary walls with double contours. Periodic-acid-Schiff stain, $\times 400$ hypercholesterolemia improved after the treatment with PSL and dipyridamole [10]. Microscopic hematuria, proteinuria and hypocomplementemia continued at 14 years of age and the follow-up renal biopsy was performed; 18 glomeruli were obtained (Fig. 2). Mesangial proliferation and capillary wall thickness were decreased. Lobulation of glomeruli was not noted. Fibro-cellular crescents in 3 glomeruli and a sclerosed glomerulus were noted. There was no tubulointerstitial change. Immunofluorescent micrograph showed dominant $\mathrm{C} 3$ deposition along the capillary walls, weak $\operatorname{IgG}$ staining and traces of $\operatorname{IgA}$ and $\operatorname{IgM}$ in the mesangium and along the capillary walls. Findings on electron microscopy were not available. Pathological findings were thought to be improved and PSL was reduced to $10 \mathrm{mg}$ on alternate days. At 16 years of age proteinuria increased to $3.4 \mathrm{~g} /$ day and she became nephrotic again. Serum creatinine level was normal $(0.45 \mathrm{mg} / \mathrm{dL})$. Intravenous methylprednisolone $500 \mathrm{mg}$ per day for 3 days was administrated followed by oral PSL $10 \mathrm{mg}$ on alternate days. Angiotensin-converting enzyme inhibitor for renoprotection was added. Hypocomplementemia improved (C3>64 mg/dL) at 19 years of age. At 25 years microscopic hematuria disappeared and hypoalbuminemia improved (serum albumin level $>2.5 \mathrm{~g} /$ $\mathrm{dL}$ ). Serum creatinine was $0.82 \mathrm{mg} / \mathrm{dL}$, estimated glomerular filtration rate (eGFR) was $71.6 \mathrm{~mL} / \mathrm{min} / 1.73 \mathrm{~m}^{2}$, and proteinuria was $3.7 \mathrm{~g} /$ day. During 26 and 32 years, her serum creatinine was between 0.85 and $1.06 \mathrm{mg} / \mathrm{dL}$, eGFR was between 51.7 and $67.2 \mathrm{~mL} / \mathrm{min} / 1.73 \mathrm{~m}^{2}$, and morning spot urine protein/creatinine ratio was between 0.2 and $0.7 \mathrm{~g} / \mathrm{gCr}$. Blood pressure was normal and treatment with PSL $10 \mathrm{mg}$ on alternate days was continued.

She wished to have a child even after the risks of maternal and neonatal complications associated with pregnancy, including preeclampsia, CKD development and preterm delivery, were explained to the patient and her husband.

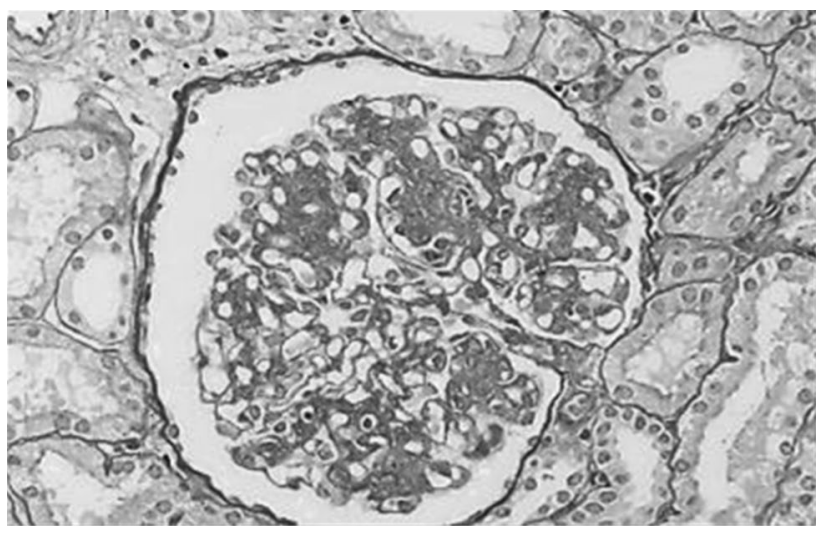

Fig. 2 Light micrograph of second renal biopsy performed at the age of 14 years old showing decreased mesangial proliferation and capillary wall thickness compared to first renal biopsy findings. Periodic-acid-Schiff stain, $\times 400$ 
She had two gestations at 32 and 33 years of age and both resulted in spontaneous abortion at 9 weeks of gestation. She received ovulation induction with human menopausal gonadotropin and human chorionic gonadotropin at another Obstetrics and Gynecology Clinic and had quintuplet gestation. At 10 weeks of gestation transvaginal selective embryo reduction procedure was performed and five embryos were reduced to twins. After the procedure, she was referred to the Department of Obstetrics and Gynecology of Omori Hospital. Her body height, weight and body mass index before pregnancy were $154 \mathrm{~cm}, 55 \mathrm{~kg}$ and $23.2 \mathrm{~kg} / \mathrm{m}^{2}$, respectively. After angiotensin-converting enzyme was discontinued at each gestation, her blood pressure was normal. At 20 weeks of the third gestation, hypertension occurred and administration of methyldopa was started. From 24 weeks she was admitted to the maternal-fetal-intensive-care-unit and antihypertensive drug was changed to nifedipine. Hypertension continued. Urinary protein excretion increased to $6.7 \mathrm{~g} / \mathrm{day}$ and nephrotic syndrome developed. Serum creatinine level increased to $1.29 \mathrm{mg} / \mathrm{dL}$ and eGFR decreased to $39.1 \mathrm{~mL} /$ $\min / 1.73 \mathrm{~m}^{2}$. Elective cesarean section was performed at 28 weeks of gestation. Twin babies were born. Male baby was $1235 \mathrm{~g}$ of weight, $34.5 \mathrm{~cm}$ of height and $29.4 \mathrm{~cm}$ of head circumstance at birth and was appropriate for date. His Apgar score was 6 at 5 min after birth. Female baby was $883 \mathrm{~g}$ of weight (below the 10th percentile for the Japanese population), $33.2 \mathrm{~cm}$ of height (above the 10th percentile) and $24.8 \mathrm{~cm}$ of head circumstance (above the 10th percentile) at birth. The asymmetrical type intrauterine growth restriction due to placental insufficiency and superimposed preeclampsia was diagnosed. Her Apgar score was 5 at $5 \mathrm{~min}$ after birth. The twins were dichorionic diamniotic and discordant. Pathology of placenta showed infarct in some focal regions without signs of chorioamnionitis. Both babies were treated with surfactant administration and mechanical ventilation for respiratory distress syndrome. By the neonatal screening tests, the female baby was diagnosed as having hypothyroidism at 1 month of age (free triiodothyronine $1.91 \mathrm{pg} / \mathrm{mL}$; normal range $2.26-4.15 \mathrm{pg} /$ $\mathrm{mL}$, free thyroxine $0.52 \mathrm{ng} / \mathrm{dL}$; normal range $1.01-1.67 \mathrm{ng} /$ $\mathrm{dL}$, thyroid stimulating hormone $150 \mu \mathrm{IU} / \mathrm{mL}$; normal range $0.32-4.12 \mu \mathrm{IU} / \mathrm{mL}$ ) and was treated with levothyroxine. Urinary iodine concentration of the baby was high $(760 \mu \mathrm{g} / \mathrm{L}$; normal range $121-271 \mu \mathrm{g} / \mathrm{L}$ ). The mother had undergone hysterosalpingography after a second abortion at 34 years of age. Excessive maternal iodine intake due to iodinated contrast medium administration may cause hypothyroidism of the baby [11]. At 3 months of age, she received laser photocoagulation for retinopathy due to prematurity. Any other congenital anomaly was not noted in both babies. They were discharged from neonatal-intensive-care-unit on day 74 and 114, respectively. A month after delivery, blood pressure, serum creatinine, eGFR and serum albumin of the mother returned to baseline levels. Nifedipine was changed to angiotensin-converting enzyme. Six months later, proteinuria decreased to $2+(1.1 \mathrm{~g} / \mathrm{gCr})$. Clinical findings of the patient are shown in Table 1.

\section{Discussion}

The effects of pregnancy on preexisting CKD depend on the severity of renal impairment and the presence of hypertension and heavy proteinuria. The prognosis of pregnancy in women with serum creatinine level of $<1.4 \mathrm{mg} / \mathrm{dL}$, normal blood pressure and no heavy proteinuria is generally considered to be good. The rate of successful pregnancy diminishes with increasing severity of CKD [6]. Neonatal mortality of low birth weight infants $(<2500 \mathrm{~g})$ in Japan decreased from $8.8 \%$ in 1980 to $0.8 \%$ in 2010 . More than $90 \%$ of infants born at 28 weeks or later survive now [3, 4]. Due to the improvement of obstetrical and perinatal care, $99 \%$ of 504 pregnancies in women with CKD stages 1-5 resulted in live births during 2000-2013. But complication rates of pregnancy remain high. Elevated blood pressure, increased proteinuria and decreased renal function during pregnancy in most women with eGFR $\geqq 60 \mathrm{~mL} / \mathrm{min} / 1.73 \mathrm{~m}^{2}$ (CKD stages 1 and 2) recovers within 6 weeks after the delivery. Renal dysfunction remained after delivery in a half of women with eGFR $<45 \mathrm{~mL} / \mathrm{min} / 1.73 \mathrm{~m}^{2}$ (CKD stage $3 \mathrm{~b}$ ). About onethird in women with eGFR $<30 \mathrm{~mL} / \mathrm{min} / 1.73 \mathrm{~m}^{2}$ (CKD stages 4 and 5) required renal replacement therapy within a year after delivery [6].

Incidence of multifetal pregnancies has been increasing, using assisted reproduction technologies and ovulationinducing hormones. In general population, outcomes of multifetal pregnancy become worse with increased number of fetuses. Gestational hypertension occurred in $7 \%$ of the mothers with singleton, $13 \%$ with twins and $20 \%$ with triplets [12]. Cesarean section was performed in about a half of twin gestations and in $90 \%$ of triplet gestations during preterm period $[13,14]$. The incidence of complications and outcomes in singleton and multifetal pregnant CKD women in two reports by Piccoli et al. $[15,16]$ are showed in Table 2. New-onset hypertension during singleton pregnancy occurred in $9 \%$ of women with CKD stages 1 and $2\left(\mathrm{eGFR} \geqq 60 \mathrm{~mL} / \mathrm{min} / 1.73 \mathrm{~m}^{2}\right)$ and $48 \%$ of women with CKD stages 3-5 (eGFR $\left.<60 \mathrm{~mL} / \mathrm{min} / 1.73 \mathrm{~m}^{2}\right)$. New onset or doubling of proteinuria during singleton pregnancy was observed in 24\% of women with CKD stages 1 and 2 and in $83 \%$ of women with CKD stages 3-5 [15]. Among 17 multifetal (15 twins and 2 triplets) pregnancies, 4 of 9 patients (44\%) with normal blood pressure before pregnancy became hypertensive and new-onset proteinuria or doubling of proteinuria occurred in 6 of 17 patients (35\%) [16]. Incidence of cesarean section and preterm delivery was high in singleton 
Table 1 Clinical course of a woman with membranoproliferative glomerulonephritis type I

\begin{tabular}{|c|c|c|c|c|c|c|c|}
\hline & $\begin{array}{l}\text { At first renal } \\
\text { biopsy }\end{array}$ & $\begin{array}{l}\text { At second renal } \\
\text { biopsy }\end{array}$ & $\begin{array}{l}\text { Before first } \\
\text { pregnancy }\end{array}$ & $\begin{array}{l}\text { Before } \\
\text { second preg- } \\
\text { nancy }\end{array}$ & $\begin{array}{l}\text { Before third } \\
\text { pregnancy }\end{array}$ & $\begin{array}{l}\text { At cesarean } \\
\text { section }\end{array}$ & $\begin{array}{l}1 \text { month after } \\
\text { delivery }\end{array}$ \\
\hline Age (years) & 11 & 14 & 31 & 32 & 34 & 35 & 35 \\
\hline $\begin{array}{l}\text { Blood pressure } \\
(\mathrm{mmHg})\end{array}$ & $104 / 50$ & $120 / 66$ & $114 / 86$ & $128 / 80$ & $110 / 70$ & $170 / 105$ & $124 / 80$ \\
\hline $\begin{array}{l}\text { Serum creatinine } \\
(\mathrm{mg} / \mathrm{dL})\end{array}$ & 0.37 & 0.44 & 0.95 & 0.89 & 0.86 & 1.29 & 0.89 \\
\hline $\begin{array}{l}\mathrm{eGFR}(\mathrm{mL} / \\
\left.\mathrm{min} / 1.73 \mathrm{~m}^{2}\right)\end{array}$ & 134.3 & 119.7 & 56.6 & 60.2 & 61.5 & 39.1 & 58.7 \\
\hline $\begin{array}{l}\text { Serum albumin } \\
(\mathrm{g} / \mathrm{dL})\end{array}$ & 2.5 & 3.9 & 3.8 & 3.5 & 3.9 & 2.4 & 3.6 \\
\hline CH50 (U/mL) & 24 & 41 & 42 & 40 & 41 & 53 & - \\
\hline C3 (mg/dL) & 21 & 55 & 85 & 83 & 85 & 116 & - \\
\hline $\mathrm{C} 4(\mathrm{mg} / \mathrm{dL})$ & 19 & 24 & 20 & 19 & 21 & 28 & - \\
\hline Hematuria $^{\mathrm{a}}$ & $3+$ & $1+$ & - & - & - & - & - \\
\hline Proteinuria $^{\mathrm{a}}$ & $3+$ & $2+$ & $2+$ & $2+$ & $1+$ & $3+$ & $3+$ \\
\hline$(\mathrm{g} / \text { day or } \mathrm{g} / \mathrm{gCr})^{\mathrm{b}}$ & $3.4 \mathrm{~g} /$ day & $1.5 \mathrm{~g} / \mathrm{day}$ & $0.5 \mathrm{~g} / \mathrm{gCr}$ & $0.7 \mathrm{~g} / \mathrm{gCr}$ & $0.2 \mathrm{~g} / \mathrm{gCr}$ & $6.7 \mathrm{~g} /$ day & $5.6 \mathrm{~g} / \mathrm{gCr}$ \\
\hline Prednisolone & $60 \mathrm{mg} /$ day & $15 \mathrm{mg} / \mathrm{ADT}$ & $10 \mathrm{mg} / \mathrm{ADT}$ & $10 \mathrm{mg} / \mathrm{ADT}$ & $10 \mathrm{mg} / \mathrm{ADT}$ & $10 \mathrm{mg} / \mathrm{ADT}$ & $10 \mathrm{mg} / \mathrm{ADT}$ \\
\hline
\end{tabular}

eGFR estimated glomerular filtration rate, CH50 complement hemolytic activity, normal CH50 28-48 U/mL, normal C3 64-166 mg/dL, normal C4 $15-38 \mathrm{mg} / \mathrm{dL}, A D T$ alternate-day administration

${ }^{\mathrm{a}}$ Grade of hematuria and proteinuria detected by dipstick

${ }^{\mathrm{b}}$ Urinary protein excretion in $24 \mathrm{~h}$ (g/day) or morning spot urine protein-to-creatinine ratio $(\mathrm{g} / \mathrm{gCr})$

Table 2 Reported complications and outcomes of singleton and multifetal pregnancy in women with chronic kidney disease

\begin{tabular}{|c|c|c|c|c|c|c|}
\hline & $\begin{array}{l}\text { Number of } \\
\text { patients }\end{array}$ & $\begin{array}{l}\text { New-onset hypertension } \\
\text { during pregnancy }(\%)\end{array}$ & $\begin{array}{l}\text { New-onset or doubling of pro- } \\
\text { teinuria during pregnancy (\%) }\end{array}$ & $\begin{array}{l}\text { Cesarean sec- } \\
\text { tion }(\%)\end{array}$ & $\begin{array}{l}\text { Preterm } \\
\text { delivery }(\%)\end{array}$ & $\begin{array}{l}\text { Neonatal } \\
\text { death } \\
(\%)\end{array}$ \\
\hline \multicolumn{7}{|c|}{ ingleton pregnancy [15] } \\
\hline CKD stages $1-2^{\mathrm{a}}$ & 457 & 9 & 24 & 52 & 29 & 0 \\
\hline CKD stages $3-5^{\mathrm{b}}$ & 47 & 48 & 83 & 77 & 81 & 2 \\
\hline \multicolumn{7}{|c|}{ Multifetal pregnancy [16] } \\
\hline CKD stages $1-2^{\mathrm{a}}$ & $17^{\mathrm{c}}$ & 44 & 35 & 100 & 94 & 7 \\
\hline
\end{tabular}

Singleton pregnancy [15]

$C K D$ chronic kidney disease

${ }^{\mathrm{a}}$ Estimated glomerular filtration rate $\geqq 60 \mathrm{~mL} / \mathrm{min} / 1.73 \mathrm{~m}^{2}$

${ }^{b}$ Estimated glomerular filtration rate $<60 \mathrm{~mL} / \mathrm{min} / 1.73 \mathrm{~m}^{2}$

${ }^{\mathrm{c}} 15$ twin and 2 triplet pregnancies

pregnancy, compared with those in general population and was over $90 \%$ in twin pregnancies. In both healthy and CKD women, singleton pregnancy was safer than multifetal pregnancy. But after the trial of induced ovulation, multifetal pregnancies are reduced to twins to increase the chances of delivering at least one viable fetus in many cases $[17,18]$.

In this paper, quintuplet gestation in a woman with MPGN type I resulted in live twin births after superimposed preeclampsia. Despite fetal reduction, preeclampsia occurred. But close follow-up by obstetricians and cesarean section at an appropriate time resulted in the successful delivery of preterm twin infants. Although hypertension, growth failure of the placenta due to PSL, and intrauterine growth restriction due to hypoproteinemia may be complicated in some cases, most women with CKD seem to have live birth recently [6]. Among 17 multifetal pregnancies reported by Piccoli et al. [16], six women had delivered the babies using assisted reproductive technologies. Incidence of multifetal pregnancies using assisted reproduction technologies in CKD women seems to be increasing. Nephrologist must know the risks of multifetal pregnancy in CKD women of childbearing age. There is no protocol about the 
management for multifetal pregnancy in CKD women. The management should be determined individually. The decision should depend on progression of CKD and maternal age. Although increased incidence of congenital abnormalities in children born to women with CKD is not reported, long term effects on mother and infant is not clear [6]. Small for gestational age babies and preterm babies may have effects on increased risks for neurological deficits and development of diabetes, metabolic syndrome, cardiovascular diseases and CKD carried into adulthood.

\section{Compliance with ethical standards}

Conflict of interest The authors have declared that no conflict of interest exists.

Human and animal rights This article does not contain any studies with human participants performed by any of the authors.

Informed consent Informed consent was obtained from all individual participants included in the article.

Open Access This article is distributed under the terms of the Creative Commons Attribution 4.0 International License (http://creativeco mmons.org/licenses/by/4.0/), which permits unrestricted use, distribution, and reproduction in any medium, provided you give appropriate credit to the original author(s) and the source, provide a link to the Creative Commons license, and indicate if changes were made.

\section{References}

1. Abe $\mathrm{S}$. An overview of pregnancy in women with underlying renal disease. Am J Kidney Dis. 1991;17:112-5.

2. Jungers P, Chauveau D. Pregnancy in renal disease. Kidney Int. 1997;52:871-85.

3. Nair D, Kidd L, Krane NK. Membranoproliferative glomerulonephritis in pregnancy. Am J Med Sci. 2017;353:320-8.

4. Horiuchi T, Ohno T, Itani Y, Kabe K, Nakamura T, Nakamura $\mathrm{H}$. Studies on the states of care for high risk neonates and neonatal mortality in our country (year 2000). J Jpn Pediatr Soc. 2002;106:603-13 (in Japanese with English abstract).

5. Kim DH, Jeon J, Park CG, Sriram S, Lee K. Neonatal and infant mortality in Korea, Japan, and the U.S.: effect of birth weight distribution and birth weight-specific mortality rates. J Korean Med Sci 2016;31:1450-4.

6. Hall M. Pregnancy in women with CKD: a success story. Am J Kidney Dis. 2016;68:633-9.

7. Motoyama O, Sakai K, Ohashi Y, Mizuiri S, Hatori T, Iitaka K, Koitabashi Y. Membranoproliferative glomerulonephritis in a girl and her mother. Clin Exp Nephrol. 2009;13:77-80.

8. Kurdoglu M, Kurdoglu Z, Adali E, Soyoral Y, Erkoc R. Successful management of membranoproliferative glomerulonephritis type I in pregnancy. Arch Gynecol Obstet. 2010;281:105-9.

9. El-Toukhy T, Bhattacharya S, Akande VA. Multiple pregnancies following assisted conception: scientific impact paper no. 22. BJOG. 2018. https://doi.org/10.1111/1471-0528.14974.

10. Motoyama O, Kawahara K, Saji T, Matsuo S, Kawamura S, Iitaka K. Onset of membranoproliferative glomerulonephritis in a 11-year-old girl with positive anti-nuclear antibody for longterm. Jpn J Pediatr Med. 1994;26:481-5 (in Japanese).

11. Satoh M, Aso K, Katagiri Y. Thyroid dysfunction in neonates born to mothers who have undergone hysterosalpingography involving an oil-soluble iodinated contrast medium. Horm Res Paediatr. 2015;84:370-5.

12. Day MC, Barton JR, O'Brien JM, Istwan NB, Sibai BM. The effect of fetal number on the development of hypertensive conditions of pregnancy. Obstet Gynecol. 2005;106:927-31.

13. Luo ZC, Simonet F, An N, Bao FY, Audibert F, Fraser WD. Effect on neonatal outcomes in gestational hypertension in twin compared with singleton pregnancies. Obstet Gynecol. 2006; 108:1138-44.

14. Luke B, Brown MB. Maternal morbidity and infant death in twin vs triplet and quadruplet pregnancies. Am J Obstet Gynecol. 2008;198:401.e1-10.

15. Piccoli GB, Cabiddu G, Attini R, Vigotti FN, Maxia S, Lepori N, Tuveri M, Massidda M, Marchi C, Mura S, Coscia A, Biolcati M, Gaglioti P, Nichelatti M, Pibiri L, Chessa G, Pani A, Todros T. Risk of adverse pregnancy outcome in women with CKD. J Am Soc Nephrol. 2015;26:2011-22.

16. Piccoli GB, Arduino S, Attini R, Parisi S, Fassio F, Biolcati M, Pagano A, Bossotti C, Vasario E, Borgarello V, Daidola G, Ferraresi $\mathrm{M}$, Gaglioti $\mathrm{P}$, Todros T. Multiple pregnancies in CKD patients: an explosive mix. Clin J Am Soc Nephrol. 2013;8:41-50.

17. Cunningham FG, Leveno KJ, Bloom SL, Hauth JC, Gilstrap LC III, Wenstrom KD. Multifetal gestation. Williams obstetrics. 22nd ed. New York: McGraw-Hill; 2005. pp. 911-48.

18. Kim MS, Choi DH, Kwon H, Ahn E, Cho HY, Baek MJ, Shin JE, Moon MJ. Procedural and obstetrical outcomes after embryo reduction or fetal reduction in multifetal pregnancies: a retrospective study. Ultrasound Obstet Gynecol. 2018. https://doi. org/10.1002/uog.19024. 